VALENTINA THERESIA

Departemen Agribisnis, Sekolah Pascasarjana, Institut Pertanian Bogor

ANNA FARIYANTI, DAN NETTI TINAPRILLA

Departemen Agribisnis, Fakultas Ekonomi dan Manajemen, Institut Pertanian Bogor

Email:valent0202@gmail.com

\section{Pengambilan Keputusan Petani Terhadap Penggunaan Benih Bawang Merah Lokal dan Impor di Cirebon, Jawa Barat}

\begin{abstract}
A deficiency of shallot seed production causes Indonesia could not meet its own local demand yet and thus imports foreign variety from other countries. However, farmer should choose between local and imported seed variety for their farming business activity. The purposes of the study was to analyze farmer decision and factors that determine farmer decision to utilize local and imported seed of shallot. Logistic regression was used to answer the research questions. Respondents were 60 persons divided into two groups, farmer who utilized local seed and that utilized the imported one. The result showed that the differences in decision making between local and imported farmers were the benefits they sought, while the factors that
\end{abstract}

significantly influence the farmer's decision to use local seed are scale of land area, seed price, income and market. Scale of land area and seed price have negative influence significantly, while income and market give positive influence significantly on farmer decision to utilize conventional seed. Keywords: farmer decision, influenced factor, shallot, local and imported seed.

\section{INTISARI}

Adanya keterbatasan produksi benih bawang merah nasional menyebabkan Indonesia belum mampu memenuhi kebutuhan benih nasional, sehingga mengimpor benih bawang merah dari negara lain. Oleh karena itu petani dihadapkan kepada suatu pilihan yaitu tetap menggunakan benih lokal atau beralih pada benih impor. Penelitian ini bertujuan untuk menganalisis pengambilan keputusan petani dan faktor-faktor yang mempengaruhi keputusan petani terhadap penggunaan benih bawang merah lokal ataupun impor. Metode analisis yang digunakan adalah Regresi Logistik. Responden penelitian terdiri dari 30 petani pengguna benih bawang merah lokal dan 30 petani pengguna benih impor. Hasil penelitian menunjukkan bahwa perbedaan pengambilan keputusan antara petani pengguna benih lokal dan impor adalah pada manfaat yang dicari petani, sedangkan faktor-faktor yang berpengaruh secara signifikan terhadap keputusan petani untuk menggunakan benih bawang merah lokal adalah luas lahan, harga benih, pendapatan, dan pemasaran. Luas lahan dan harga benih berpengaruh negatif, sedangkan pendapatan dan pemasaran berpengaruh positif terhadap penggunaan benih. Kata kunci: pengambilan keputusan petani, faktor yang berpengaruh, bawang merah, benih lokal dan impor.

\section{PENDAHULUAN}

Bawang merah merupakan salah satu komoditas sayuran yang memiliki nilai ekonomis tinggi ditinjau dari sisi pemenuhan konsumsi nasional, sumber penghasilan petani dan potensinya sebagai penghasil devisa negara. 
Selain itu, bawang merah termasuk salah satu komoditas sayuran unggulan nasional yang telah lama diusahakan petani secara intensif.

Petani bawang merah menggunakan bermacam-macam varietas, baik yang lokal maupun impor. Tingginya kebutuhan benih bawang merah baik dalam bentuk benih komersial maupun benih sumber, belum diikuti produksi benihnya. Selain itu petani bawang merah di Indonesia nampaknya sangat tergantung terhadap benih impor seperti varietas Ilokos, Super Philip dan varietas lain yang berasal dari Thailand, India, dan Vietnam. Padahal benih bawang merah varietas impor yang tersebar di Indonesia merupakan bawang merah untuk konsumsi yang disimpan 2-3 bulan.

Rendahnya produksi benih bawang merah nasional disebabkan belum banyaknya produsen yang mau bergerak di bidang perbenihan bawang merah (Indarawati dan Padmono, 2001). Kendala tersebut disebabkan antara lain: i) usaha perbenihan bawang merah membutuhkan modal yang cukup tinggi, disamping areal dan gudang yang luas; ii) pengetahuan dan ketrampilan SDM terutama dalam produksi benih masih rendah; iii) daya simpan benih bawang merah rendah (2-5 bulan) dengan susut bobot yang tinggi; iv) permasalahan penyimpanan benih dapat diatasi dengan pembentukan benih berupa biji, namun sayangnya ketrampilan ini cukup sulit diaplikasikan pada petani.

Adanya keterbatasan produksi benih bawang merah nasional menyebabkan Indonesia belum mampu memenuhi kebutuhan benih nasional. Oleh karena itu Indonesia mengimpor benih bawang merah dari beberapa negara seperti Philipina, Vietnam, dan Thailand. Dengan hadirnya benih bawang merah impor, petani dihadapkan kepada suatu pilihan yaitu meneruskan usahataninya dengan tetap menggunakan benih varietas lokal atau beralih dari varietas lokal dan kemudian menggunakan benih varietas impor. Benih bawang merah impor tidak langsung diterima oleh petani, namun mereka mempunyai pertimbanganpertimbangan tersendiri sebelum menggunakan sesuatu yang baru. Akhirnya petani bawang merah terkelompokkan menjadi dua bagian, yaitu petani yang menggunakan benih bawang merah lokal dan petani yang menggunakan benih bawang merah impor.

Petani sebagai individu pembuat keputusan selalu dipengaruhi oleh ketersediaan sumberdaya rumah tangganya dan juga oleh hubungan sosialnya, yaitu keputusan suatu masyarakat akan mempengaruhi keputusan individu. Disamping itu perilaku budidaya juga saling berhubungan dengan perilaku sosial, budaya, ekonomi dan perilaku dari kehidupan masyarakat pedesaan. Bentuk interaksi antar faktor-faktor tersebut pada akhirnya merupakan faktor penentu dalam pembuatan keputusan oleh petani (Suek, 1994; Gilbert dan Norman, 1980).

Terkait dengan alternatif pilihan benih bawang merah yang dihadapi petani, menarik untuk ditelaah bagaimana proses pengambilan keputusan petani dalam penggunaan benih bawang merah lokal dan impor serta faktor-faktor apa saja yang mempengaruhi keputusan petani menggunakan benih bawang merah lokal.

\section{METODE PENELITIAN}

Penelitian dilakukan di Kecamatan Gebang dan Pabedilan, Kabupaten Cirebon, Provinsi Jawa Barat. Penentuan lokasi penelitian tersebut dengan menggunakan metode purposive sampling dengan dasar pertimbangan Kabupaten Cirebon merupakan salah satu daerah sentra pengembangan bawang merah terbesar di Jawa Barat. Penelitian dilaksanakan pada bulan November 2014 sampai dengan November 2015. Jenis data yang digunakan adalah data primer dan sekunder. Data primer diperoleh melalui observasi dan wawancara secara langsung berdasarkan kuesioner kepada responden. Penentuan sampel dilakukan secara purposive pada petani pengguna benih lokal dan impor. Responden penelitian berjumlah 60 orang yang terdiri dari 30 orang petani pengguna benih lokal dan 30 orang petani pengguna benih impor. Data sekunder diperoleh dari hasil penelitian PKHT (Pusat Kajian Hortikultura Tropika) IPB tahun 2014. Analisis data dilakukan dengan menggunakan Regresi Logistik dan pendugaan parameter fungsi logit dengan menggunakan metode Maximum Likelihood Estimation (MLE). Fungsi tersebut dirumuskan sebagai berikut:

$$
\begin{gathered}
\mathrm{Y}_{\mathrm{i}}=\operatorname{Ln}\left[\frac{p i}{1-p i}\right]=\mathrm{a}^{+} \hat{\mathrm{a}}_{1} \mathrm{X}_{1}+\hat{\mathrm{a}}_{2} \mathrm{X}_{2}+\hat{\mathrm{a}}_{3} \mathrm{X}_{3}+\hat{a}_{4} \mathrm{X}_{4} \hat{\mathrm{a}}_{5} \mathrm{X}_{5}+\hat{a}_{6} \mathrm{X}_{6}+ \\
\hat{\mathrm{a}}_{7} \mathrm{X}_{7}+\hat{\mathrm{a}}_{8} \mathrm{X}_{8}+\ddot{\mathrm{e}} \mathrm{D}
\end{gathered}
$$

dimana :

$\mathrm{Y}_{\mathrm{i}} \quad=$ Peluang petani menggunakan benih bawang merah lokal/impor

$\mathrm{Y}_{\mathrm{i}} \quad=1$ jika petani menggunakan benih bawang merah lokal 
$\mathrm{Y}_{\mathrm{i}} \quad=0 \mathrm{jika}$ petani menggunakan benih bawang merah impor

á $\quad=$ Intersep

$\mathrm{X}_{1} \quad=$ Pengalaman berusahatani bawang merah (tahun)

$\mathrm{X}_{2}=$ Luas lahan usahatani (ha)

$\mathrm{X}_{3}=$ Status kepemilikan lahan (1=milik, $0=$ non milik $)$

$\mathrm{X}_{4} \quad=$ Harga benih $(\mathrm{Rp})$

$\mathrm{X}_{5} \quad=$ Harga jual produk $(\mathrm{Rp})$

$\mathrm{X}_{6}=$ Produktivitas (ton $\left./ \mathrm{ha}\right)$

$\mathrm{X}_{7} \quad=$ Pendapatan $(\mathrm{Rp})$

$\mathrm{X}_{8} \quad=$ Pemasaran $(1=$ mudah, $\mathrm{O}=$ sulit $)$

âi $\quad=$ Parameter peubah $\mathrm{X}_{\mathrm{i}}$

ë $\quad=$ Parameter peubah dummy

\section{HASIL DAN PEMBAHASAN}

\section{KARAKTERISTIK RESPONDEN PETANI BAWANG MERAH}

Karakteristik responden merupakan ciri spesifik dari seseorang seperti umur, tingkat pendidikan, pengalaman usahatani, luas lahan, dan status kepemilikan lahan (Tabel 1). Penelitian Asih (2009) di Sulawesi mengungkap bahwa karakteristik berupa umur, pendidikan, dan status usahatani berpengaruh terhadap keterampilan petani dalam mengelola usahatani bawang merah.

Petani bawang merah baik yang menggunakan benih lokal maupun impor didominasi oleh petani yang berada pada kisaran umur produktif yaitu antara 20 - 55 tahun. Pada umumnya orang-orang yang berusia produktif memiliki semangat yang tinggi untuk mengembangkan usahanya, karena terdorong oleh kebutuhan yang tinggi dan mampu melakukan usahatani bawang merah dengan lebih baik dibandingkan dengan petani yang relatif lebih tua.

Tingkat pendidikan petani responden baik yang menggunakan benih lokal maupun impor masih didominasi oleh pendidikan sekolah dasar. Hal ini berarti bahwa sebagian besar petani responden memiliki tingkat pendidikan formal yang masih rendah. Hal ini tentunya akan berpengaruh pada tingkat keberanian mengambil keputusan dan risiko dalam pengelolaan usahatani bawang merah. Hal tersebut sesuai dengan penelitian Emiria, et. al. (2014) yang menyatakan bahwa keterbatasan dana mengakibatkan banyak petani yang memilih untuk tidak bersekolah lagi dan meneruskan pekerjaan orang tuanya sebagai petani.

Pada petani bawang merah baik yang menggunakan benih lokal maupun impor, sebagian besar memiliki pengalaman berusahatani antara 1-10 tahun. Pengalaman berusahatani menunjukkan lamanya petani berkecimpung dalam usahatani bawang merah. Semakin lama pengalaman usahataninya maka dapat disimpulan bahwa petani tersebut sudah memahami teknik budidaya dalam kegiatan usahataninya.

Lahan merupakan basis dalam kegiatan usahatani yang berperan sebagai salah satu modal dalam pertanian selain tenaga kerja dan kapital. Responden petani bawang merah yang menggunakan benih lokal di Kecamatan Gebang dan Pabedilan, Kabupaten Cirebon, pada umumnya tergolong ke dalam petani berskala menengah dengan pengusahaan lahan antara 0,5 - 1 hektar, sedangkan petani bawang merah yang menggunakan benih impor, sebagian besar tergolong ke dalam petani berskala besar dengan pengusahaan lahan lebih dari 1 hektar.

Status kepemilikan lahan petani baik yang menggunakan benih lokal maupun impor sebagian besar

TABEL I. KARAKTERISTIK RESPONDEN PETANI BAWANG MERAH

\begin{tabular}{llllll}
\hline \multirow{2}{*}{ No } & \multirow{2}{*}{ Karakteristik } & \multicolumn{2}{l}{ Petani benih lokal } & Petani benih impor & \\
& & Kategori & Persentase (\%) & Kategori & Persentase (\%) \\
\hline 1 & Umur (tahun) & $46-55$ & 53,33 & $36-45$ dan $46-55$ & 33,33 \\
2 & Tingkat pendidikan & SD & 36,67 & SD & 40,00 \\
3 & Pengalaman usaha tani (tahun) & $1-10$ & 36,67 & $1-10$ & 30,00 \\
4 & Luas lahan (Ha) & $0,5-1,0$ & 46,67 & $>1,0$ & 53,33 \\
5 & Status kepemilikan lahan & Sewa & 93,33 & Sewa & 86,67 \\
\hline
\end{tabular}


TABEL 2. PENGENALAN MASALAH ATAU KEBUtUHAN PETANI PENGGUNA BENIH LOKAL DAN IMPOR

\begin{tabular}{|c|c|c|c|c|c|}
\hline \multirow[b]{2}{*}{ No } & \multirow[b]{2}{*}{ Uraian } & \multicolumn{2}{|l|}{ Benih Lokal } & \multicolumn{2}{|l|}{ Benih Impor } \\
\hline & & $\begin{array}{l}\text { Jumlah Responden } \\
\text { (Orang) }\end{array}$ & $\begin{array}{l}\text { Persentase } \\
(\%)\end{array}$ & $\begin{array}{l}\text { Jumlah Responden } \\
\text { (Orang) }\end{array}$ & $\begin{array}{l}\text { Persentase } \\
(\%)\end{array}$ \\
\hline \multirow[t]{4}{*}{1} & Motivasi berusahatani bawang merah & & & & \\
\hline & a. Memperoleh keuntungan & 16 & 53,33 & 13 & 43,33 \\
\hline & b. Turun-temurun & 7 & 23,33 & 16 & 53,33 \\
\hline & c. Memenuhi kebutuhan sendiri & 7 & 23,33 & 1 & 3,33 \\
\hline \multirow[t]{4}{*}{2} & Motivasi menggunakan benih & & & & \\
\hline & a. Harga terjangkau & 3 & 10,00 & 5 & 16,67 \\
\hline & b. Mudah didapat & 1 & 3,33 & 3 & 10,00 \\
\hline & c. Kualitas bagus & 26 & 86,67 & 22 & 73,33 \\
\hline \multirow[t]{4}{*}{3} & Manfaat yang dicari & & & & \\
\hline & a. Meningkatkan jumlah produksi & 5 & 16,67 & 27 & 90,00 \\
\hline & b. Meningkatkan kualitas produksi & 17 & 56,67 & 3 & 10,00 \\
\hline & $\begin{array}{l}\text { c. Mengurangi terkena hama dan } \\
\text { penyakit }\end{array}$ & 8 & 26,67 & - & - \\
\hline
\end{tabular}

lahan garapannya merupakan lahan sewaan. Alasan utama petani melakukan sewa tanah adalah karena adanya keterbatasan lahan yang dimilikinya sehingga pada akhirnya untuk dapat melakukan usaha budidaya bawang mereka, mereka mencari lahan sewa dari petani lain.

\section{PROSES PENGAMBILAN KEPUTUSAN PENGGUNAAN BENIH}

Proses pengambilan keputusan petani dalam menggunakan benih bawang merah lokal ataupun impor melalui 5 tahapan, yaitu: pengenalan masalah atau kebutuhan, pencarian informasi, evaluasi alternatif, keputusan pembelian, dan perilaku pasca pembelian.

Pengenalan masalah atau kebutuhan. Proses penggunaan benih bawang merah lokal ataupun impor diawali ketika petani mulai merasakan dan mengenali adanya kebutuhan akan suatu produk benih, dan berusaha untuk memenuhi kebutuhan tersebut (Tabel 2). Bagi masyarakat di Kabupaten Cirebon, berusahatani bawang merah sudah menjadi pekerjaan utama bagi mereka. Motivasi petani dalam berusahatani bawang merah sangat beragam. Pada petani yang menggunakan benih lokal sebagian besar atau sekitar 53,33 persen adalah untuk memperoleh keuntungan; sedangkan pada petani yang menggunakan benih impor, sebagian besar atau sekitar 53,33 persen adalah karena faktor turuntemurun.

Kebutuhan terhadap benih bawang merah didorong oleh beberapa faktor dan hal ini dipengaruhi oleh motivasi petani dalam menggunakan benih. Hasil penelitian menunjukkan bahwa pada petani benih lokal dan impor, timbulnya motivasi petani dalam menggunakan benih bawang merah lokal sebagian besar karena kualitasnya yang bagus. Manfaat yang dicari petani dalam penggunaan benih bagi petani benih lokal sebagian besar adalah untuk meningkatkan kualitas produksi $(56,67 \%)$. Lain halnya dengan petani benih impor, sebagian besar petani menyatakan bahwa manfaat yang dicari dalam penggunaan benih impor adalah untuk meningkatkan jumlah produksi (90\%). Menurut Ancok (1997), adanya pengetahuan tentang manfaat sesuatu hal akan menyebabkan seseorang bersikap positif terhadap hal tersebut.

Pencarian informasi. Pada tahap ini petani akan melakukan pencarian informasi mengenai keunggulan dan kelemahan benih yang akan dipergunakan pada usahataninya. Perolehan informasi akan mempengaruhi persepsi petani bahkan keyakinannya terhadap benih, sehingga pada akhirnya akan mempengaruhi keputusan dalam penggunaan benih. Dalam mengusahakan usahataninya para petani menentukan jenis benih yang 
TABEL 3.SUMBER INFORMASI YANG MEMPENGARUHI PENGGUNAAN BENIH

\begin{tabular}{lllll}
\hline \multirow{2}{*}{ Uraian } & \multicolumn{2}{l}{ Benih Lokal } & \multicolumn{3}{l}{ Benih Impor } \\
\cline { 2 - 5 } & $\begin{array}{l}\text { Jumlah } \\
\text { Responden } \\
\text { (Orang) }\end{array}$ & $\begin{array}{l}\text { Persentase } \\
(\%)\end{array}$ & $\begin{array}{l}\text { Jumlah Responden } \\
\text { (Orang) }\end{array}$ & $\begin{array}{l}\text { Persentase } \\
(\%)\end{array}$ \\
\hline a. Dir sendiri & 6 & 20,00 & 17 & 56,67 \\
b. Kelompok tani/teman/keluarga & 20 & 66,67 & 7 & 23,33 \\
c. Pedagang benih & 4 & 13,33 & 6 & 20,00 \\
\hline
\end{tabular}

TABEL 4. EVALUASI ALTERNATIF PETANI PENGGUNA BENIH LOKAL DAN IMPOR

\begin{tabular}{|c|c|c|c|c|c|}
\hline \multirow[b]{2}{*}{ No } & \multirow[b]{2}{*}{ Uraian } & \multicolumn{2}{|l|}{ Benih Lokal } & \multicolumn{2}{|l|}{ Benih Impor } \\
\hline & & $\begin{array}{l}\text { Jumlah Responden } \\
\text { (Orang) }\end{array}$ & Persentase (\%) & $\begin{array}{l}\text { Jumlah Responden } \\
\text { (Orang) }\end{array}$ & Persentase (\%) \\
\hline \multirow[t]{4}{*}{1} & Informasi penting & & & & \\
\hline & a. Harga & 5 & 16,67 & 1 & 3,33 \\
\hline & b. Produktivitas & - & - & 28 & 3,33 \\
\hline & c. Kualitas & 25 & 83,33 & 1 & 93,33 \\
\hline \multirow[t]{4}{*}{2} & Pertimbangan memilih & & & & \\
\hline & $\begin{array}{l}\text { a. Kebiasaan yang telah } \\
\text { dilakukan }\end{array}$ & 23 & 76,67 & 24 & 80,00 \\
\hline & b. Mengikuti petani lain & 2 & 6,67 & 3 & 10,00 \\
\hline & c. Laku di pasaran & 5 & 16,67 & 3 & 10,00 \\
\hline
\end{tabular}

akan digunakannnya selain karena memiliki pengetahuan sendiri, juga sangat dipengaruhi oleh pihak lain. Sumber informasi interpersonal yang biasa dimanfaatkan petani untuk memperoleh informasi adalah sesama petani atau orangtua, petugas penyuluh lapangan, pedagang, dan distributor.

Dari Tabel 3 dapat dilihat bahwa petani lain/ kelompok tani $(66,67 \%)$ menjadi sumber informasi yang paling berpengaruh bagi petani pengguna benih bawang merah lokal. Petani dan kelompok tani merupakan sumber informasi yang paling bisa dipercaya oleh petani, karena mereka melihat sendiri produktivitas benih yang digunakan. Sementara sumber informasi terbesar petani pengguna benih bawang merah impor, berasal dari diri sendiri $(56,67 \%)$. Hal ini dikarenakan para petani tersebut sudah merasa yakin dengan kualitas benih impor. Hal ini sesuai dengan pernyataan Setiadi (2010) bahwa informasi yang diperoleh konsumen pada umumnya banyak berasal dari sumber komersial, tetapi informasi paling efektif berasal dari sumber pribadi.

Evaluasi alternatif. Pada tahap ini petani membuat pertimbangan terbaik yang harus diambil dalam memenuhi kebutuhannya dengan cara memilih kriteriakriteria tertentu yang relevan dengan keinginan dan kebutuhan untuk membuat keputusan penggunaan benih. Berdasarkan Tabel 4, benih bawang merah yang beredar di Kabupaten Cirebon cukup banyak varietasnya dan bisa dibedakan menjadi benih varietas lokal dan impor. Informasi penting yang dicari oleh petani dalam penggunaan benih lokal sebagian besar karena kualitas (83.33 persen); sedangkan untuk benih impor, sebagian besar karena produktivitas (93.33 persen). Faktor yang menjadi pertimbangan bagi petani untuk memilih menggunakan benih bawang merah lokal ataupun impor, sebagian besar dikarenakan kebiasaan yang telah dilakukan.

Keputusan pembelian. Pada tahap ini, petani mengambil keputusan mengenai benih apa yang akan 
TABEL 5. KEPUTUSAN PEMBELIAN PETANI PENGGUNA BENIH LOKAL DAN IMPOR

\begin{tabular}{|c|c|c|c|c|c|}
\hline \multirow[b]{2}{*}{ No } & \multirow[b]{2}{*}{ Uraian } & \multicolumn{2}{|l|}{ Benih Lokal } & \multicolumn{2}{|l|}{ Benih Impor } \\
\hline & & $\begin{array}{l}\text { Jumlah Responden } \\
\text { (Orang) }\end{array}$ & Persentase (\%) & $\begin{array}{l}\text { Jumlah Responden } \\
\text { (Orang) }\end{array}$ & Persentase (\%) \\
\hline \multirow[t]{4}{*}{1} & Cara pembelian benih & & & & \\
\hline & a. Terencana & 28 & 93,33 & 28 & 93,33 \\
\hline & b. Tergantung situasi & 2 & 6,67 & 1 & 3,33 \\
\hline & c. Mendadak & & - & 1 & 3,33 \\
\hline \multirow[t]{4}{*}{2} & Yang berpengaruh dalam proses pembelian & & & & \\
\hline & a. Diri sendiri & 19 & 63,33 & 23 & 76,67 \\
\hline & b. Kelompok tani/teman/keluarga & 11 & 36,67 & 5 & 16,67 \\
\hline & c. Toko pertanian/penjual & & & 2 & 6,67 \\
\hline \multirow[t]{8}{*}{3} & Sumber benih & & & & \\
\hline & a. Membuat sendiri & 4 & 13,33 & & - \\
\hline & b. Membeli dari petani lain di Kab. Cirebon & 1 & 3,33 & & - \\
\hline & c. Membeli dari petani lain di Kab. Brebes & 18 & 60,00 & & - \\
\hline & d. Membeli di petani \& membuat sendiri & 1 & 3,33 & & \\
\hline & e. Membeli dari bandar/tengkulak benih & 6 & 20,00 & & \\
\hline & f. Koperasi & & & 1 & 3,33 \\
\hline & g. Importir & & - & 29 & 96,67 \\
\hline \multirow[t]{3}{*}{4} & Jarak tempat pembelian & & & & \\
\hline & a. $1-5 \mathrm{~km}$ & 2 & 6,67 & 12 & 40,00 \\
\hline & b. Lebih dari $5 \mathrm{~km}$ & 28 & 93,33 & 18 & 60,00 \\
\hline
\end{tabular}

digunakan dalam usahataninya (Tabel 5). Menurut Engel et al. (1994), niat pembelian digolongkan menjadi dua kategori yaitu pembelian terencana dan pembelian tidak terencana. Hasil penelitian menunjukkan bahwa petani pengguna benih lokal dan impor melakukan pembelian benih sebagian besar secara terencana. Petani melakukan pembelian benih secara terencana karena sudah mempunyai jadwal tanam bawang merah yang akan dilakukan pada bulan-bulan tertentu, sehingga perlu adanya stok benih untuk masa tanam berikutnya. Pada umumnya para petani bawang membeli benih bawang merah lokal segar yang baru dipanen.

Penggunaan benih oleh petani di Kecamatan Gebang dan Pabedilan, Kabupaten Cirebon selain ditentukan oleh diri sendiri, juga dipengaruhi oleh pihak luar. Hasil penelitian menunjukkan bahwa bagi petani pengguna benih lokal dan impor, yang berpengaruh dalam proses pembelian benih sebagian besar adalah diri sendiri.

Dalam proses pembelian, konsumen harus memutuskan dimana memperoleh produk yang diinginkan. Sebagian besar petani (60\%) memperoleh benih bawang merah lokal dengan cara membeli dari petani bawang merah di Kabupaten Brebes. Para petani tersebut mengakui bahwa benih bawang merah lokal yang berasal dari Kabupaten Brebes memiliki kualitas yang bagus. Petani yang menjual benih berkualitas bagus, walaupun tempatnya jauh dari tempat petani, maka petani akan tertarik untuk membeli benihnya. Selain membeli dari petani di Kabupaten Brebes, ada juga petani yang membeli benih dari petani bawang merah di Kabupaten Cirebon ataupun dari bandar atau tengkulak. Selain membeli, beberapa petani memperoleh benih dengan cara membuat benih sendiri, yaitu dengan menyisihkan sebagian hasil panennya untuk dijadikan benih pada saat musim tanam berikutnya. Ada beberapa hal yang menyebabkan petani menggunakan benih sendiri, yaitu karena mereka sudah terbiasa menggunakan benih sendiri dan merasa yakin bahwa benih yang mereka 
TABEL 6. PERILAKU PASCA PEMBELIAN PETANI PENGGUNA BENIH LOKAL DAN IMPOR

\begin{tabular}{|c|c|c|c|c|c|}
\hline \multirow[b]{2}{*}{ No } & \multirow[b]{2}{*}{ Uraian } & \multicolumn{2}{|l|}{ Benih Lokal } & \multicolumn{2}{|l|}{ Benih Impor } \\
\hline & & $\begin{array}{l}\text { Jumlah Responden } \\
\text { (Orang) }\end{array}$ & $\begin{array}{l}\text { Persen- } \\
\text { tase (\%) }\end{array}$ & $\begin{array}{l}\text { Jumlah Responden } \\
\text { (Orang) }\end{array}$ & $\begin{array}{l}\text { Persen- } \\
\text { tase }(\%)\end{array}$ \\
\hline \multirow[t]{3}{*}{1} & Kepuasan pembelian benih & & & & \\
\hline & a. Puas & 30 & 100,00 & 19 & 63,33 \\
\hline & b. Tidak puas & - & - & 11 & 36,67 \\
\hline \multirow[t]{3}{*}{2} & Jika harga benih naik & & & & \\
\hline & a. Tetap membeli & 20 & 66,67 & 25 & 83,33 \\
\hline & b. Tidak membeli & 10 & 33,33 & 5 & 16,67 \\
\hline \multirow[t]{3}{*}{3} & Jika varietas benih tidak tersedia di pasaran & & & & \\
\hline & a. Mencari di tempat lain & 28 & 93,33 & 23 & 76,67 \\
\hline & b. Membeli varietas lain & 2 & 6,67 & 7 & 23,33 \\
\hline
\end{tabular}

miliki sama hasilnya dengan benih yang dibeli pada petani lain. Selain itu karena harga benih yang cukup mahal, sedangkan pembuatan benih tidaklah sulit dan produksinya tidak berbeda jauh dibandingkan benih yang baru.

Jarak tempat pembelian benih dengan tempat tinggal petani di Kecamatan Gebang dan Pabedilan relatif jauh. Pada petani benih lokal, jarak tempat pembelian benih sebagian besar adalah lebih dari $5 \mathrm{~km}$ (93,33\%). Hal ini karena sebagian besar petani pengguna benih lokal membeli benih bawang merah lokal dari petani-petani di Kabupaten Brebes. Begitu pula pada petani benih impor, jarak tempat pembelian sebagian besar adalah lebih dari $5 \mathrm{~km}(60 \%)$. Petani benih impor membeli benih impor dari para importir yang letaknya jauh dari tempat tinggal mereka.

Perilaku pasca pembelian. Setelah petani responden menggunakan benih, maka akan timbul suatu perubahan dalam menilai hasil usahataninya dengan berdasarkan pada kenyataan yang sesuai di lapangan (Tabel 6). Seluruh petani responden yang menggunakan benih bawang merah lokal menyatakan puas dengan benih yang digunakannya. Mereka mengaku bahwa benih yang digunakannya memiliki kualitas yang bagus dan juga hasil produksinya yang sesuai dengan keinginan petani. Namun lain halnya dengan petani yang menggunakan benih bawang merah impor, hanya 63,33 persen petani yang menyatakan puas dengan benih impor yang digunakannya karena kualitasnya yang bagus. Mereka memiliki keluhan karena kualitas benih yang tidak bagus dan pertumbuhannya yang tidak seragam. Semakin tinggi tingkat kepuasan petani dalam menggunakan suatu varietas benih, maka akan semakin tinggi pula keinginan petani untuk menggunakan benih tersebut. Respon positif petani terhadap benih akan mempengaruhi terhadap penggunaan benih selanjutnya.

Keadaan konsumen dalam membeli suatu produk sangat dipengaruhi oleh harga produk itu sendiri. Hasil penelitian menunjukkan bahwa apabila harga benih bawang merah baik lokal maupun impor mengalami kenaikan, maka sebagian besar petani masih akan tetap membeli benih tersebut. Hal ini karena para petani tersebut sudah sangat yakin dengan kualitasnya yang terjamin.

Keputusan penggunaan suatu jenis benih juga sangat dipengaruhi oleh ketersediaan benih. Hasil penelitian menunjukkan bahwa apabila benih yang akan digunakan tidak tersedia di lapang, maka sebagian besar petani pengguna benih lokal dan impor akan mencari benih tersebut di tempat lain. Hal ini berarti bahwa baik petani pengguna benih lokal maupun impor sebagian besar memiliki tingkat loyalitas yang tinggi pada benih yang biasa mereka gunakan, sehingga apabila benih tersebut tidak tersedia di lapang maka mereka akan mencari di tempat lain.

\section{FAKTOR-FAKTOR YANG MEMPENGARUHI KEPUTUSAN PETANI TERHADAP PENGGUNAAN}




\section{BENIH BAWANG MERAH LOKAL}

Analisis regresi logistik digunakan untuk mengetahui faktor-faktor yang mempengaruhi keputusan petani dalam menggunakan benih bawang merah lokal ataupun impor. Variabel respon $(\mathrm{Y})$ pada analisis ini berupa kategorik, dimana petani bawang merah yang menggunakan benih lokal diberi nilai 1 dan petani bawang merah yang menggunakan benih impor diberi nilai 0. Berdasarkan literatur sebelumnya dan atas pertimbangan kenyataan pada lokasi penelitian, ada 8 variabel bebas yang diduga mempengaruhi keputusan petani untuk menggunakan benih bawang merah lokal. Kedelapan variabel bebas tersebut adalah pengalaman usahatani, luas lahan, status lahan, harga benih, harga jual, produktivitas, pendapatan, dan pemasaran.

Untuk melihat ketepatan model digunakan nilai Nagelkerke R square sebesar 0,851. Nilai ini menunjukkan bahwa kemampuan variabel independen dalam menjelaskan variabel dependen adalah sebesar 0,851 atau 85,1 persen sedangkan sisanya sebesar 14,9 persen dijelaskan oleh variabel lain di luar model. Untuk menguji signifikansi dari model dalam memodelkan data digunakan uji kebaikan model atau goodness-of-fit yang dilakukan dengan menggunakan metode HosmerLemeshow (H-L). Hasil uji dari model tersebut dengan nilai statistik H-L test adalah 1,229 dan nilai p-value atau signifikansi yang dihasilkan adalah 0,996. Nilai p-value lebih besar dari taraf nyata 5 persen, sehingga dapat disimpulkan bahwa model logit tersebut layak untuk digunakan karena secara keseluruhan mampu menjelaskan atau memprediksi keputusan petani dalam menggunakan benih bawang merah lokal.

Hasil dugaan model regresi logistik menunjukkan pada tingkat kepercayaan 95 persen (á=5\%) ada empat variabel yang memberikan pengaruh nyata terhadap keputusan petani dalam menggunakan benih bawang merah lokal. Variabel tersebut adalah luas lahan, harga benih, pendapatan, dan pemasaran. Empat variabel lainnya yaitu pengalaman usahatani, status kepemilikan lahan, harga jual, dan produktivitas tidak memberikan pengaruh nyata. Hasil pengolahan data untuk melihat variabel bebas yang secara nyata mempengaruhi variabel terikat dengan menggunakan regresi logistik disajikan pada Tabel 7 .

Luas Lahan. Variabel luas lahan memiliki nilai signifikansi sebesar 0,014 , sehingga variabel ini berpengaruh signifikan terhadap keputusan petani menggunakan benih bawang merah lokal. Variabel luas lahan memiliki nilai koefisien yang negatif, hal ini berarti bahwa peluang petani menggunakan benih bawang merah lokal berhubungan negatif dengan luas lahan, sehingga semakin luas lahan yang dimiliki petani maka kemungkinan petani menggunakan benih bawang merah lokal akan semakin kecil. Nilai odds ratio pada variabel luas lahan adalah 0,017 yang berarti bahwa setiap adanya peningkatan luas lahan sebesar 1 hektar maka peluang petani untuk menggunakan benih bawang merah lokal sebesar 0,017 kali (ceteris paribus).

Rata-rata petani bawang merah yang menggunakan benih lokal memiliki luas lahan seluas 0,81 hektar, sedangkan petani yang menggunakan benih bawang merah impor rata-rata memiliki lahan seluas 1,72 hektar.

TABEL 7. HASIL ANALISIS LOGIT UNTUK FAKTOR-FAKTOR YANG MEMPENGARUHI PENGGUNAAN BENIH BAWANG MERAH LOKAL

\begin{tabular}{llllllll}
\hline No. & Variabel & B & S.E. & Wald & df & Sig. & Exp (B) \\
\hline 1 & Pengalaman usahatani & $-0,77$ & 0,63 & 1,484 & 1 & 0,223 & 0,926 \\
2 & Luas lahan & $-4,073$ & 1,655 & 6,058 & 1 & 0,014 & 0,017 \\
3 & Status lahan & $-1,309$ & 1,906 & 0,472 & 1 & 0,492 & 0,270 \\
4 & Harga benih & $-0,001$ & 0,000 & 5,131 & 1 & 0,023 & 0,999 \\
5 & Harga jual & 0,001 & 0,001 & 2,372 & 1 & 0,123 & 1,001 \\
6 & Produktivitas & 0,000 & 0,000 & 1,611 & 1 & 0,204 & 1,000 \\
7 & Pendapatan & 0,000 & 0,000 & 4,508 & 1 & 0,034 & 1,000 \\
8 & Pemasaran & 2,897 & 1,358 & 4,549 & 1 & 0,033 & 18,119 \\
& Constant & 6,518 & 7,977 & 0,668 & 1 & 0,414 & 677,412 \\
\hline
\end{tabular}


Hal tersebut menunjukkan bahwa petani bawang merah yang menggunakan benih lokal memiliki lahan yang lebih kecil dibandingkan dengan petani yang menggunakan benih impor. Petani yang memiliki lahan yang lebih sempit memiliki kecenderungan untuk tetap mempertahankan pola tanam yang sudah ada sebelumnya, yaitu dengan menggunakan benih bawang merah lokal karena alasan besarnya risiko dan ketidakpastian produksi dan pemasaran yang mungkin terjadi pada benih bawang merah impor. Pada umumnya petani yang memiliki lahan yang kecil memiliki modal usahatani yang tidak terlalu besar, sehingga peluangnya menggunakan benih bawang merah lokal lebih besar karena harga beli benih lokal lebih murah.

Harga Benih. Variabel harga benih memiliki nilai signifikansi sebesar 0,023, sehingga variabel ini berpengaruh signifikan terhadap keputusan petani menggunakan benih bawang merah lokal. Variabel harga benih memiliki nilai koefisien yang negatif, hal ini berarti bahwa peluang petani menggunakan benih bawang merah lokal berhubungan negatif dengan harga benih; semakin tinggi harga benih, kemungkinan petani menggunakan benih bawang merah lokal akan semakin kecil. Nilai odds ratio pada variabel harga benih sebesar 0,999 yang berarti bahwa setiap adanya peningkatan harga benih sebesar Rp 1 maka peluang petani untuk menggunakan benih bawang merah lokal sebesar 0,999 kali (cateris paribus).

Menurut Schiffman dan Kanuk (2008), Joni et al. (2001), harga merupakan salah satu dari beberapa faktor yang mempengaruhi konsumen dalam keputusan membeli benih. Demikian juga dengan Sumiati (2006) yang menyatakan bahwa salah satu faktor yang mempengaruhi keputusan petani menggunakan benih padi adalah harga benih. Harga benih benih yang mahal menyebabkan petani tidak mampu membeli benih yang mengakibatkan areal pengusahaan bawang merah cenderung menurun. Hal ini sesuai dengan hasil penelitian Ginting et al. (2013) yang menunjukkan bahwa koefisien harga benih juga bernilai negatif yang menandakan bahwa semakin tinggi harga benih, maka keinginan petani untuk memperluas areal tanam bawang merah semakin kecil.

Berdasarkan penelitian, harga bawang merah yang menggunakan benih lokal memiliki nilai terendah sebesar Rp 10.000/kg dan harga tertinggi mencapai Rp $27.000 / \mathrm{kg}$. Sementara itu, harga bawang merah yang menggunakan benih impor memiliki nilai terendah sebesar Rp 16.000/kg dan harga tertinggi mencapai Rp $35.000 / \mathrm{kg}$. Variasi harga benih impor lebih beragam dibandingkan dengan benih lokal. Pada umumnya para petani bawang merah mengatakan bahwa harga benih bawang merah lokal yang rendah sebagai alasan mereka menggunakan benih lokal. Hanya petani yang memiliki modal besar yang biasanya membeli benih impor.

Pendapatan. Variabel pendapatan berpengaruh signifikan terhadap keputusan petani menggunakan benih bawang merah lokal. Variabel pendapatan memiliki nilai koefisien positif, hal ini berarti bahwa peluang petani menggunakan benih bawang merah lokal berhubungan positif dengan pendapatan, sehingga semakin besar pendapatan yang diterima petani maka peluang petani untuk menggunakan benih bawang merah lokal juga semakin besar. Nilai odds ratio pada variabel pendapatan adalah 1 yang berarti bahwa setiap adanya peningkatan pendapatan sebesar Rp 1 maka peluang petani menggunakan benih bawang merah lokal sebesar 1 kali (cateris paribus).

Petani bawang merah pengguna benih lokal rata-rata memperoleh pendapatan sebesar Rp 31.429.052 sedangkan pendapatan petani pengguna benih impor sebesar Rp 77.763.015. Hal ini menunjukkan bahwa pendapatan petani benih lokal lebih kecil dibandingkan dengan petani benih impor. Besarnya nilai pendapatan yang diperoleh petani dari usahatani bawang merah akan menjadi pertimbangan bagi petani dalam mengambil keputusan mengenai input produksi yang akan digunakannya. Hal ini sependapat dengan Crissman dan Hibon (1996) bahwa keputusan petani untuk melakukan pembelian benih berdasarkan pada keuntungan atau pendapatan yang diperoleh selama beberapa kali musim. Begitu pula menurut Bishop dan Toussaint (1989), pendapatan para petani dapat dipengaruhi oleh pemilihan mereka atas hasil-hasil produksi. Pemilihan hasil-hasil produksi tersebut dilakukan oleh petani berdasarkan pendapatan yang mereka harapkan dan penjualan hasil produksi yang diusahakan. Oleh karena itu sebelum memilih dan mengusahakan suatu komoditi, petani akan mempertimbangkan besar kecilnya pendapatan yang diperoleh dari pengusahaan komoditi tersebut.

Pemasaran. Variabel akses pasar berpengaruh signifikan terhadap keputusan petani menggunakan benih bawang merah lokal. Variabel akses pasar memiliki nilai koefisien yang positif, hal ini berarti bahwa peluang petani menggunakan benih bawang merah lokal 
berhubungan positif dengan akses pasar, sehingga semakin mudah akses pasarnya maka peluang petani untuk menggunakan benih bawang merah lokal juga semakin besar. Nilai odds ratio pada variabel akses pasar sebesar 18.199 yang berarti bahwa apabila akses pasarnya mudah maka peluang petani menggunakan benih lokal adalah 18.199 kali lebih besar dibandingkan dengan yang pemasarannya sulit (cateris paribus).

Benih bawang merah lokal memiliki akses pasar yang lebih mudah. Pada umumnya petani menjual hasil panennya kepada tengkulak/pedagang pengumpul tingkat desa. Sistem penjualan dilakukan secara borongan ataupun tebas, yaitu berdasarkan taksiran jumlah panen. Tingkat harga yang diterima oleh petani berdasarkan pada permintaan pasar dan tingkat produksi bawang merah pada sentra-sentra produksi bawang merah. Pada saat panen raya dimana produksi berlimpah, maka harga bawang merah cenderung turun. Namun apabila stok produksi relatif rendah dibandingkan dengan permintaan pasar, maka harga bawang merah akan meningkat.

Berbeda halnya dengan benih bawang merah impor. Produksi bawang merah yang menggunakan benih impor apabila memiliki kualitas produksi yang bagus maka bisa dijual kepada eksportir, namun apabila kualitas produksinya jelek maka hanya bisa dijual ke pasar lokal. Kemudahan bawang merah untuk dijual berkaitan erat dengan penerimaan pasar dari bawang merah baik bagi petani, pedagang, maupun konsumen.

Variabel Lain. Hasil uji regresi logistik menunjukkan bahwa variabel pengalaman usahatani, status kepemilikan lahan, harga jual, dan produktivitas memiliki nilai signifikansi lebih besar dari 0,05. Hal ini berarti variabel tersebut tidak berpengaruh secara signifikan untuk ikut menentukan peluang petani dalam menggunakan benih bawang merah lokal.

Berdasarkan kenyataan di lapangan, proses perubahan sikap petani terhadap penggunaan benih bawang merah lokal tidak dipengaruhi oleh pengalaman berusahatani tetapi dipengaruhi oleh bukti yang telah dilihat di lingkungan sekitarnya. Petani cenderung mengamati dan menilai hasil dari petani lain yang telah lebih dahulu menggunakan benih bawang merah lokal. Setelah mengetahui keunggulan benih bawang merah lokal dibandingkan benih impor, maka mereka baru tertarik untuk menggunakan benih lokal.

\section{KESIMPULAN}

Pengambilan keputusan penggunaan benih bawang merah lokal dan impor oleh petani melalui tahap pengenalan kebutuhan, pencarian informasi, evaluasi alternatif, keputusan pembelian, dan evaluasi pasca pembelian. Perbedaan pengambilan keputusan antara petani pengguna benih lokal dan impor terdapat pada manfaat yang dicari petani, yakni pada petani pengguna benih lokal untuk meningkatkan kualitas produksi, sedangkan bagi petani pengguna benih impor untuk meningkatkan jumlah produksi.

Faktor yang berpengaruh secara signifikan terhadap keputusan petani untuk menggunakan benih bawang merah lokal adalah luas lahan, harga benih, pendapatan, dan akses pasar. Luas lahan dan harga benih berpengaruh negatif dan signifikan, sedangkan pendapatan dan pemasaran berpengaruh positif dan signifikan terhadap keputusan petani untuk menggunakan benih bawang merah lokal.

\section{DAFTAR PUSTAKA}

Ancok, D. 1997. Teknik Penyusunan Skala Pengukur. Yogyakarta: Pusat Penelitian Kependudukan UGM. Asih, D.N. 2009. Analisis karakteristik dan tingkat pendapatan usahatani bawang merah di Sulawesi Tengah. Jurnal Agroland 16 (1): 53-59.

Bishop dan Toussaint. 1989. Pengantar Analisis Ekonomi Pertanian. Jakarta: Mutiara.

Crissman, C., and A. Hibon. 1996. Establishing Seed Potato Prices: Concepts, Procedures and Implications for Research and Training. Working Paper, Social Science Department. 1996-1. CIP. Lima Peru.

Emiria, F. dan H. Purwandari. 2014. Pengembangan pertanian organik di Kelompok Tani Madya, Desa Kebonagung, Kabupaten Bantul, Daerah Istimewa Yogyakarta. Jurnal Penyuluhan 10 (2).

Engel, J.F., R.D. Blackwell, dan P.W. Miniard. 1995. Perilaku Konsumen Jilid 1 (6th ed). Jakarta: Binarupa Aksara.

Gilbert, E., and D.W. Norman. 1980. A General Overview of Farming System Research dalam Reading in Farming System Research and Development. Westview Press.

Ginting, M., T. Sebayang, dan Iskandarini. 2013. Analisis Pengaruh Faktor Sosial Ekonomi Petani terhadap Luas 
Tanam Bawang Merah Berdasarkan Pendapatan Petani di Kabupaten Dairi. Universitas Sumatera Utara.

Joni, M.M.A, M.F.R. Rubzen, and P.J.Batt. 2001. Factors influencing a farmer's decision to purchase seed potatoes in East Java. Paper presented at the $45^{\text {th }}$ Annual Conference of the Australian Agricultural and Resource Economics Society, Adelaide, South Australia.

Kotler, P. 2000. Marketing Management, Analysis, Planning, Implementation Control (7th ed). USA: Printice Hall.

Schiffman, and Kanuk. 2008. Perilaku KonsumenEd 7. Jakarta: PT. Indeks.

Setiadi N.J. 2003. Perilaku Konsumen; Konsep dan implikasi untuk Strategi dan Penelitian Pemasaran. Jakarta: Prenada Media.

Suek, J. 1994. Faktor-Faktor Penentu Keputusan Petani Memilih Pola Agroforestri Tradisional Antar Zona di Kawasan Timor Barat. Tesis, Program Pascasarjana, Institut Pertanian Bogor. 